\title{
Analisis Aktivitas dan Hasil Belajar Siswa Ditinjau Dari Tipologi Belajar Siswa Kelas VII SMP Negeri 1 Sekampung Udik
}

\author{
Siti Qomariyah¹, Ummi Rosyidah ${ }^{2}$ \\ ${ }^{1}$ Pendidikan Matematika, STKIP Tunas Palapa, sitiqomariyah.iqom@gmail.com \\ ${ }^{2}$ Pendidikan Matematika, Universitas Nahdlatul Ulama Lampung, ummirosyium09@gmail.com
}

\section{INFO ARTIKEL}

Riwayat Artikel:

Diterima: 02-02-2018

Disetujui: 26-03-2018

\section{Kata Kunci:}

Aktivitas

Hasil belajar siswa

Tipologi belajar

\section{A. LATAR BELAKANG}

Pendidikan merupakan salah satu faktor yang penting dalam perkembangan dan pembangunan suatu negara. Hal ini dikarenakan orang berpendidikan akan dapat memberikan kontribusi yang positif kepada negara dalam bentuk pembangunan, khususnya pembangunan sumber daya manusia. Untuk mewujudkan hal tersebut, peran yang sangat penting dalam meningkatkan kualitas Sumber Daya Manusia (SDM) adalah pendidikan.

Proses pendidikan ke arah pencapaian tujuan tersebut tidak terlepas dari peran seorang guru di dalam suatu lembaga pendidikan. Aktivitas dalam kegiatan pembelajaran merupakan bagian yang sangat penting, karena proses pembelajaran tidak akan berjalan dengan baik tanpa adanya siswa yang aktif dan kreatif dalam proses pembelajaran. Proses pendidikan pada saat ini lebih menitikberatkan pada aktivitas atau keikutsertaan siswa dalam proses pembelajaran sehingga kegiatan pembelajaran akan berjalan dengan baik.
Hasil belajar merupakan perolehan siswa setelah mengikuti serangkaian proses pembelajaran. Hasil belajar yang berupa nilai-nilai ini diharapkan tidak sekedar menjadi bukti bahwa siswa telah menempuh serangkaian pembelajaran dan menguasai materi pelajaran yang diajarkan guru. Demikian pula dalam proses pembelajaran matematika, perlu ditanamkan kesadaran pada siswa, bahwa pengetahuan matematika yang mereka miliki secara tidak dirasakan akan terus bertambah apabila mereka memiliki keaktifan membaca buku.

Semakin aktif membaca buku, memiliki kecenderungan seseorang semakin banyak mengingat, memahami atau menguasai suatu ilmu tertentu. Jika hal ini dikaitkan dengan hasil belajar, maka dapat dikatakan bahwa semakin banyak membaca buku pelajaran sekolah termasuk dalam hal ini materi pelajaran matematika, maka akan semakin besar kemungkinan bagi siswa untuk mencapai hasil belajar yang tinggi, dan demikian pula sebaliknya. 
Hal ini menunjukkan bahwa pencapaian hasil belajar merupakan hal terpenting dalam belajar. Upaya siswa untuk mewujudkan hasil belajar dapat dipengaruhi oleh berbagai faktor, baik yang bersumber dari diri siswa maupun dari luar diri siswa. Hasil belajar pada hakikatnya merupakan fenomena yang memiliki ketergantungan terhadap faktor-faktor tertentu.

Pendidikan di sekolah pada hakikatnya merupakan proses perubahan perilaku anak. Hal ini menunjukkan bahwa di dalam proses belajar untuk mencapai suatu tujuan itu anak didik memerlukan dukungan dari faktor lingkungan terdekatnya, di antaranya guru dan sumber serta sarana. Sedangkan belajar itu sendiri ditinjau dari segi tahapannya, yaitu mengenal, memahami kemudian menguasai suatu pengetahuan. Proses mengenal dapat dialami oleh setiap manusia, termasuk dalam hal ini siswa melalui melihat, memandang atau merasakan, termasuk melalui membaca.

Berdasarkan hasil prasurvei yang penulis lakukan di SMP Negeri 1 Sekampung Udik, dari data yang diperoleh terlihat bahwa siswa yang tuntas KKM (Kriteria Kelulusan Minimum) dengan dengan yang tidak tuntas KKM memiliki presentasi jauh berbeda. Hal ini dapat terlihat pada tabel berikut:

TABEL 1

DAFTAR NILAI SEMESTER GANJIL

\begin{tabular}{ccccc}
\hline No & Nilai & Kategori & $\begin{array}{c}\text { Jumlah } \\
\text { Siswa }\end{array}$ & Persentase \\
\hline 1 & $\geq 70$ & Tuntas & 3 & $12,50 \%$ \\
\hline 2 & $<70$ & $\begin{array}{l}\text { Tidak } \\
\text { Tuntas }\end{array}$ & 21 & $87,50 \%$ \\
\hline \multicolumn{5}{c}{ Jumlah } \\
\hline
\end{tabular}

Berdasarkan hasil dari pengamatan saat proses pembelajaran berlangsung penulis mendapati ada sebagian siswa yang hanya ngobrol dengan rekannya, tidak mengerjakan PR (Pekerjaan Rumah), tidak mencatat dari apa yang dijelaskan oleh guru, cenderung masih pasif dalam mengeluarkan pendapat, bahkan ada sebagian siswa tidak memperhatikan penjelasan guru.

Berdasarkan uraian di atas, dapat diketahui bahwa setiap siswa memiliki tipologi belajar yang berbeda-beda. Jika seorang guru dapat mengetahui cara belajar yang diinginkan siswa, tentu saja hasil belajar yang diinginkan akan tercapai.

Adapun tujuan yang ingin dicapai melalui penelitian ini adalah: 1) Untuk mengetahui tipologi belajar siswa kelas VII.E SMP Negeri 1 Sekampung Udik. 2) Untuk mendeskripsikan gambaran aktivitas belajar siswa ditinjau dari tipologi belajar kelas VII.E SMP Negeri 1 Sekampung Udik. 3) Untuk mengetahui hasil belajar siswa ditinjau dari tipologi belajar kelas VII.E SMP Negeri 1 Sekampung Udik.

Gagne dalam [3] belajar merupakan suatu sistem yang didalamnya terdapat berbagai unsur yang saling terkait sehingga menghasilkan perubahan perilaku. Aktivitas tidak dimaksudkan terbatas aktivitas fisik, akan tetapi juga meliputi aktivitas yang bersifat psikis seperti aktivitas mental [8]. Hasil belajar adalah kemampuan-kemampuan yang dimiliki siswa setelah menerima pengalaman belajarnya [4].

Pegertian tipologi menurut [7] menyatakan bahwa, "Tipologi belajar adalah kombinasi dari bagaimana seseorang menyerap, kemampuan mengatur dan mengolah informasi. Dalam buku Quantum Learning karya Bobby de Potter dkk, disebutkan tiga macam belajar yaitu tipologi belajar visual, audiotorial dan kinestetik". Orang tidak hanya cenderung pada satu modalitas, mereka juga memanfaatkan kombinasi modalitas yang memberi mereka bakat dan kekurangan alami tertentu.

\section{B. METODE PENELITIAN}

Jenis penelitian yang digunakan adalah deskriptif kualitatif karena penelitian ini berhubungan dengan penelitian lapangan, yaitu suatu metode untuk menemukan data yang spesifik dan realistik apa yang terjadi dalam proses pembelajaran. Dalam penelitian ini yang dijadikan subjek penelitian adalah siswa kelas VII.E SMP Negeri 1 Sekampung Udik.

Teknik pengumpulan data dalam penelitian ini yaitu dengan menggunakan metode angket, observasi dan tes. Adapun instrumen angket terdiri dari 30 item, 10 item untuk pernyataan tipe visual, 10 item untuk pernyataan auditorial dan 10 item untuk pernyataan kinestetik. Sedangkan untuk soal tes terdiri dari 6 soal uraian dengan materi bilangan bulat.

\section{HASIL DAN PEMBAHASAN}

Berdasarkan analisis data siswa memiliki tipologi belajar yang berbeda-beda. Hasil analisis angket diperoleh bahwa dari 32 siswa kelas VII.E SMP Negeri 1 Sekampung Udik terdapat 12 siswa yang memiliki tipe belajar visual, 11 siswa yang memiliki tipe belajar audiotorial dan 7 siswa yang memiliki tipe belajar kinestetik yang disajikan pada uraian berikut: 
TABEL 2

HASIL OBSERVASI TENTANG AKTIVITAS DITINJAU DARI TIPOLOGI BELAJARNYA

\begin{tabular}{|c|c|c|c|}
\hline $\begin{array}{c}\text { Aktivitas } \\
\text { Pembelajran } \\
\end{array}$ & Visual & $\begin{array}{l}\text { Audio } \\
\text { torial }\end{array}$ & $\begin{array}{c}\text { Kines } \\
\text { tetik }\end{array}$ \\
\hline $\begin{array}{l}\text { 1. Memperhatikan } \\
\text { penjelasan guru }\end{array}$ & $93,75 \%$ & $90,91 \%$ & $92,14 \%$ \\
\hline $\begin{array}{l}\text { 2. Bertanya kepada } \\
\text { guru }\end{array}$ & $2,08 \%$ & $6,82 \%$ & $0,00 \%$ \\
\hline $\begin{array}{l}\text { 3. Menjawab } \\
\text { pertanyaan }\end{array}$ & $4,17 \%$ & $4,55 \%$ & $0,00 \%$ \\
\hline $\begin{array}{l}\text { 4. Mengerjakan soal } \\
\text { latihan }\end{array}$ & $97,92 \%$ & $95,45 \%$ & $92,86 \%$ \\
\hline $\begin{array}{l}\text { 5. Mencatat hal-hal } \\
\text { yang dianggap } \\
\text { penting }\end{array}$ & $83,33 \%$ & $81,82 \%$ & $82,14 \%$ \\
\hline 6. Berdiskusi & $18,75 \%$ & $9,09 \%$ & $14,29 \%$ \\
\hline $\begin{array}{l}\text { Persentase Rata- } \\
\text { rata }\end{array}$ & $56,25 \%$ & $55,91 \%$ & $\begin{array}{c}\mathbf{5 1 , 4 3} \\
\%\end{array}$ \\
\hline
\end{tabular}

Kemudian untuk hasil belajar siswa setelah dianalisis diketahui bahwa hanya terdapat 6 siswa yang lulus KKM, dimana:

a. Siswa tipe visual hanya 3 siswa yang lulus KKM

b. Siswa tipe audiotorial hanya 2 siswa yang lulus KKM

c. Siswa tipe kinestetik hanya 1 siswa yang lulus KKM

TABEL 3

PERHITUNGAN BESAR PERSENTASE SETIAP TIPE BELAJAR

\begin{tabular}{cc}
\hline \multicolumn{1}{c}{ Visual } & Audiotorial \\
\hline$X \%=\frac{\sum S}{N} \times 100 \%$ & $X \%=\frac{\sum S}{N} \times 100 \%$ \\
$X \%=\frac{3}{32} \times 100 \%$ & $X \%=\frac{2}{32} \times 100 \%$ \\
$X \%=9,38 \%$ & $X \%=6,25 \%$ \\
\hline Kinestetik & Rata-Rata \\
\hline$\%=\frac{\sum S}{N} \times 100 \%$ & $\bar{X}=\frac{\sum N}{\sum S}$ \\
$X \%=\frac{1}{32} \times 100 \%$ & $\bar{X}=\frac{1467}{32}$ \\
$X \%=3,13 \%$ & $\bar{X}=45,84$ \\
\hline
\end{tabular}

Berdasarkan tabel di atas, maka dapat diketahui bahwa jumlah siswa tipe visual lebih banyak yang lulus KKM dibandingkan dengan siswa audiotorial dan kinestetik. Sedangkan untuk nilai rata-rata kelas memiliki tingkat yang rendah dibawah nilai KKM, yaitu dengan nilai 45,84.

\section{Aktivitas Belajar ditinjau dari Tipologi Belajar}

a. Aktivitas Memperhatikan Penjelasan Guru

Berdasarkan hasil observasi dalam proses pembelajaran berlangsung, diperoleh bahwa pada saat guru menerangkan materi pelajaran,hampir semua siswa sangat antusias dalam memperhatikan penjelasan guru, hal tersebut dapat dilihat pada tabel di atas dimana pelajar visual 93,75\%, pelajar audiotorial 90,91\%, dan kinestetik 92,14\% dalam memperhatikan penjelasan guru.

Memperhatikan penjelasan guru merupakan salah satu syarat mutlak agar dapat memahami materi pelajaran yang diberikan. Hal tersebut sesuai menurut [1] Apabila kita memandang ataupun memperhatikan segala sesuatu untuk mencapai tujuan yang mengakibatkan perkembangan dari kita, maka dalam hal ini kita sudah belajar.

b. Aktivitas Bertanya Kepada Guru

Berdasarkan hasil observasi, hampir semua siswa malu bahkan takut untuk bertanya kepada guru meskipun hal itu dapat menyebabkan siswa kurang memahami materi yang disampaikan. Dalam proses pembelajaran bertanya merupakan kegiatan yang selalu merupakan bagian yang tak terpisahan. Para ahli percaya pertanyaan yang baik memiliki dampak yang positif terhadap siswa [8]. Bahkan pada saat pertemuan yang lain tak ada satupun siswa yang bertanya tentang materi pelajaran, mereka hanya diam. Bahkan pada saat pertemuan yang lain tak ada satupun siswa yang bertanya tentang materi pelajaran, mereka hanya diam.Hal tersebut dapat dilihat pada tabel di atas bahwa aktivitas bertanya kepada guru memiliki persentase rendah, dan lebih didominasi oleh siswa tipe audiotorialyaitu sebesar 6,82\%, kemudian tipe visual sebesar 2,08\% sedangkan siswa tipe kinestetiktidak ada aktivitas bertanya kepada guru.

\section{c. Aktivitas Menjawab Pertanyaan}

Ketika seorang guru selesai menjelaskan materi pelajaran, dan sudah tidak ada lagi pertanyaan dari siswa maka sesekali guru mengajukan pertanyaan kepada siswa. Hal ini dilakukan agar membantu mengembalikan dan meningkatkan konsentrasi belajar siswa. Hal tersebut sesuai bahwa guru melontarkan pertanyaan itu mempunyai tujuan, agar siswa dapat mengerti atau mengingat-ingat tentang fakta yang dipelajari, didengar ataupun dibaca sehingga mereka memiliki pengertian yang mendalam tentang fakta itu [6]. Berdasarkan hasil observasi yang penulis lakukan, dalam 
aktivitas mejawab pertanyaan guru memiliki persentase rendah dikarenakan guru sebagai seorang pendidik tidak banyak memberikan pertanyaan yang diajukan kepada siswa tentang materi pelajaran. Dimana persentase terbesar menjawab pertanyaan guru terdapat pada siswa tipe auditorial yaitu sebesar 4,55\% kemudian siswa tipe visual 4,17\%, sedangkan untuk siswa tipe kinestetik tidak ada aktifitas menjawab pertanyaan dari guru,

d. Aktivitas Mengerjakan Soal atau Latihan

Dalam proses pembelajaran, mengerjakan latihan atau tugas adalah hal yang sangat penting. Hal ini disebabkan semakin banyak siswa mengerjakan soal atau latihan, maka semakin banyak penguasaan konsep yang dipahami siswa. Hal tersebut sesuai menurut [1] orang yang melaksanakan latihan tentunya sudah mempunyai dorongan untuk mencapai tujuan tentunya yang dapat mengembangkan sesuatu aspek pada dirinya. Hanya saja antusias mereka dalam mengerjakan latihan atau tugas yang berbeda. Ada sebagian siswa yang dapat menyelesaikan soal latihan lebih cepat, tetapi ada juga sebagian siswa yang menyelesaikan soal latihan sedikit lambat. Berdasarkan hasil observasi, dapat dilihat bahwa besar persentase aktivitas mengerjakan soal atau latihan didominasi oleh siswa bertipe visual, dimana besar persentasenya adalah 97,92\%, kemudian siswa bertipeaudiotorial sebesar 95,45\%, dan siswa bertipe kinestetik sebesar 92,14\%. Hanya saja antusias mereka dalam mengerjakan latihan atau tugas yang berbeda. Ada sebagian siswa yang dapat menyelesaikan soal latihan lebih cepat, tetapi ada juga sebagian siswa yang menyelesaikan soal latihan sedikit lambat.

Walaupun siswa sangat antusias dalam mengerjakan soal atau latihan namun tidak sedikit siswa yang mengerjakan soal tersebut mengalami kesulitan dan belum benar hasil jawabannya.

e. Aktivitas Mencatat Hal-hal yang Dianggap Penting

Ketika guru sedang menjelaskan materi pelajaran, aktivitas mencatat hal-hal yang dianggap penting cukup baik. Mencatat yang termasuk sebagai belajar yaitu apabila dalam mencatat itu orang menyadari kebutuhan dan tujuannya, serta menggunakan set tertentu agar catatan itu nantinya berguna bagi pencapaian tujuan belajar [1].

Berdasarkan hasil dari observasi setelah guru menjelaskan materi pelajaran dan menulisnya dipapan tulis, sebagian besar siswa menuliskannya ke buku mereka, walaupun materi tersebut sudah ada di dalam buku LKS. Dan ada juga sebagian kecil siswa yang tidak menulisnya, mereka hanya sibuk mengobrol dengan rekan semeja. Dimana aktivitas mencatat hal-hal yang dianggap penting siswa yang bertipe visual besar persentasenya yaitu 83,33\%, siswa tipe audiotorial $81,82 \%$, dan siswa tipe kinestetik $82,14 \%$.

\section{f. Aktivitas Berdiskusi}

Berdiskusi di dalam kelas biasanya dilakukan ketika para siswa dihadapkan pada suatu masalah tertentu dan siswa dituntut untuk dapat menyelesaikannya. Hal ini dilakukan untuk melatih siswa berani mengemukakan pendapat.

Diskusi kelas adalah strategi yang berguna untuk merangsang pemikiran kritis menyemangati siswa untuk memeriksa kembali sikapnya. Agar upaya diskusinya efektif, siswa harus memiliki sejumlah informasi umum tentang topic yang tengah dipertimbangkan [5].

Hasil observasi, persentase aktivitas diskusi sedikit kecil, karena diskusi tersebut hanya pada saat siswa mengerjakan soal atau latihan, dan mereka berdiskusi dengan rekan semejanya. Saat proses pembelajaran berlangsung tidak ada diskusi kelas.

\section{Hasil Belajar ditinjau dari Tipologi Belajar Siswa}

a. Tipe visual

Siswa tipe visual yang lulus berdasarkan nilai standar KKM mata pelajaran matematika adalah sebesar 9,38\%. Berdasarkan hasil observasi yang penulis lakukan, dapat diketahui bahwa siswa visual selain aktif dalam mendengarkan penjelasan guru saat menerangkan materi pelajaran, mereka juga lebih aktif mengerjakan soal atau latihan serta mencatat hal-hal yang dianggap penting. Pembelajaran melalui penglihatan cenderung memproses informasi melalui apa yang mereka lihat, berfikir dalam gambar-gambar dan memiliki imajinasi yang subur [5]. 
b. Tipe audiotorial

siswa tipe auditorial yang lulus berdasarkan nilai standar KKM mata pelajaran Matematika adalah sebesar 6,25\%. Pada siswa audiotorial, mereka lebih aktif saat bertanya kepada guru dan menjawab pertanyaan guru, serta hasil belajarnya cukup baik dari pada siswa yang bertipe kinestetik. Pembelajaran melalui pendengaran berhubungan dengan informasi melalui apa yang mereka dengar, mereka lebih senang menikmati mendengar dan suka merampungkan segala sesuatu melalui percakapan [5].

c. Tipe kinestetik

siswa tipe kinestetik yang lulus berdasarkan nilai standar KKM mata pelajaran Matematika adalah sebesar 3,13\%. Hasil belajar siswa tipe kinestetik memiliki nilai terendah jika dibandingkan dengan siswa tipe visual dan tipe auditorial. Hal ini dikarenakan siswa kinestetik lebih menyukai mata pelajaran yang banyak melakukan praktek. Pembelajan kinestetis menguasai informasi dengan cara menyentuh, meraba dan mengalami [5].

\section{SIMPULAN DAN SARAN}

Berdasarkan analisis dan pembahasan yang telah penulis lakukan dalam penelitian ini, maka penulis dapat menyimpulkan bahwa: 1) Tipologi belajar pada siswa kelas VII.E SMP Negeri 1 Sekampung Udik Tahun Pelajaran 2016/2017 sangat beragam, dari 32 siswa terdapat 12 siswa bertipe belajar visual, 11 siswa bertipe belajar auditorial dan 7 siswa bertipe belajar kinestetik. 2) Aktivitas yang terjadi pada siswa kelas VII.E SMP Negeri 1 Sekampung Udik sangat beragam ketika proses pembelajaran. Pada aktivitas memperhatikan penjelasan guru, mengerjakan soal atau latihan serta mencatat hal-hal yang dianggap penting didominasi oleh siswa yang memiliki tipe belajar visual. Kemudian aktivitas bertanya kepada guru, dan menjawab pertanyaan guru didominasi oleh siswa yang memiliki tipe belajar auditorial. Sedangkan siswa yag bertipe kinestetik cenderung diantara keduanya bahkan sangat pasif. 3) Hasil belajar siswa kelas VII.E SMP Negeri 1 Sekampung Udik cukup rendah, dari 32 siswa hanya 6 siswa yang lulus, dimana siswa tipe visual dari 12 siswa hanya 3 siswa yang lulus, kemudian siswa tipe Audiotorial dari 11 siswa hanya
2 siswa yang lulus, dan siswa tipe kinestetik dari 7 siswa hanya 1 siswa yang lulus.

Adapun saran dalam penelitian ini adalah:

1. Bagi guru, hendaknya dapat mengetahui terlebih dahulu tipologi belajar siswanya sebelum proses pembelajaran dimulai, kemudian menggunakan metode pembelajaran yang bervariasi agar siswa tidak merasa bosan atau jenuh ketika proses pembelajaran berlangsung. Dimana siswa tipe kinestetik memiliki aktivitas dan hasil belajar terendah dibandingkan dengan siswa tipe visual dan auditorial, disini guru harus menyediakan media ataupun alat peraga agar siswa yang bertipe kinestetik dapat terlayani dengan baik dan bisa meningkatkan aktivitas serta hasil belajar siswa tersebut.

2. Bagi sekolah, agar dapat menyediakan media pembelajaran yang mendukung proses pembelajaran siswa yang sesuai dengan tipologi belajar para siswanya, sehingga siswa dapat lebih tertarik dan aktivitas serta hasil belajarnya dapat meningkat.

3. Bagi siswa, setelah mengetahui tipe belajar yang ia miliki, hendaknya siswa menggunakan kemampuannya untuk lebih optimal agar dalam setiap pembelajaran bisa lebih mudah untuk memahami materi yang diajarkan.

\section{REFERENSI}

[1] Abu, A, dan Supriyono, W. (2008). Psikologi Belajar Edisi Revisi. Jakarta: Rineka Cipta

[2] Ary, N. (2007). Quantum Teaching: mempraktekkan Quantum Learning diruang-ruang kelas. Bandung: Kaifa

[3] Karwono dan Mularsih, H. (2010). Belajar dan Pembelajaran serta Pemanfaatan Sumber Belajar, Ciputat: Cerdas Jaya.

[4] Nana, S. (2010). Penilaian Hasil Poses Belajar Mengajar, Bandung: Remaja Rosdakarya.

[5] Partin, R, L. (2009). Kiat nyaman mengajar di dalam kelas, Edisi ke-2, Jilid 1. Indonesia: Indeks.

[6] Roestiyah. (2008). Strategi belajar mengajar. Jakarta: Rineka Cipta.

[7] Suparman, S. (2010). Gaya Mengajar yang Menyenangkan. Yogyakarta: Pinus Book Publisher.

[8] Wina, S. (2008). Strategi Pembelajaran berorientasi Standar Proses Pendidikan. Jakarta: Kencana. 